\title{
Career Decision-making Difficulties among Secondary School Students in Nigeria
}

\author{
Grace Omejevwe Akpochafo
}

Department of Guidance and Counselling, Delta State University, Nigeria

Received August 10, 2020; Revised September 10, 2020; Accepted October 19, 2020

\section{Cite This Paper in the following Citation Styles}

(a): [1] Grace Omejevwe Akpochafo , "Career Decision-making Difficulties among Secondary School Students in Nigeria," Universal Journal of Educational Research, Vol. 8, No. 11B, pp. 5918 - 5925, 2020. DOI: 10.13189/ujer.2020.082226.

(b): Grace Omejevwe Akpochafo (2020). Career Decision-making Difficulties among Secondary School Students in Nigeria. Universal Journal of Educational Research, 8(11B), 5918 - 5925. DOI: 10.13189/ujer.2020.082226.

Copyright $\mathrm{C} 2020$ by authors, all rights reserved. Authors agree that this article remains permanently open access under the terms of the Creative Commons Attribution License 4.0 International License

\begin{abstract}
Career decision is a process that secondary school students must undergo. Many students find it difficult due to the obstacles that they may encounter. The problem of this study, therefore, is what these difficulties are and whether they differ on gender basis. Two research questions and one hypothesis guided the study. The sample size was 341 students made up of 161 males and 180 females. The instrument for data collection was the Career Decision Making Difficulties Questionnaire (CDDQ), developed by Gati et al (1996). The reliability of the instrument was ascertained with Cronbach alpha reliability coefficient and a coefficient of 0.90 was obtained for the whole instrument. Data were analysed using mean, standard deviation and independent samples t-test. The results revealed that secondary school students are confronted with career decision-making difficulties in nine out of the ten levels used for the study. Moreover, gender was not significant except for one out of the ten distinct levels. The conclusion was drawn that students are faced with career decision-making difficulties and that there were no gender differences in all the difficulty levels.
\end{abstract}

Keywords Career Decision-making Difficulties, Gender, Taxonomy of Career Problems, Decision Theory, Career, Decision-making Difficulty Questionnaire (CDDQ)

\section{Introduction}

A career decision is one of the crucial decisions that students have to make as they grow up (Bimrose and Mulrey, 2015; Gati and Tal, 2008). This entails choosing from different occupations, training institutions, taking a job and these pose a lot of problems and difficulties to students. When these difficulties are not properly handled, they might lead students to take inappropriate decisions. To assist students in making desirable decisions, it is expedient to fully comprehend the complex process of career decision making (Gati and Levin, 2015). Hirschi (2018) asserted that in this era of the industrial revolution, students' career decision making has been affected due to information and technology revolution.

Career decision affects all facets of the individual's life hence difficulties on their way must be addressed to enable students to make appropriate decisions. It certainly affects their well-being (Creed, Prideaux, and Patto, 2005) standard of living (Sabates, Gutmon \& Schaon, 2017), those with whom they will work with their lifestyle and job satisfaction (Amir and Gati, 2006).

These complexities and barriers that arise in career decision making can be influenced by many factors, (Gati, 1986; Krieshok, Black and Mckay, 2009; Savemann, 2005) namely, career options from which selection is to be made, issues to be examined, doubts about themselves, compromise to be made and social barriers. In light of these, some students make their career decisions with ease while others have a lot of difficulties in contending within the process.

Identifying such difficulties is a crucial step in assisting students. Numerous researches show that students all over the world grapple to make decisions in respect of their 
future career (Amir and Gati, 2006; Bacanli, 2008; Bacanli, 2012, Wierik, Beishuizenandts, 2014; Di Fabio, et al., 2015; Guan, et al., 2015; Mau, 2004). Career counselling aims to assist students to make good decisions. It, therefore, becomes pertinent that school counsellors know the difficulties that students might face and how to overcome them.

Apart from the difficulties, gender is another variable considered in this study. The study ascertained if there are gender differences in career decision difficulties faced by secondary school students. The result is expected to help school counsellors know what counselling strategies to use and areas of need to the students. Studies abound on gender and career difficulties but none has used the career decision difficulty scale. Some authors believe that there are no gender differences while others stated that there are. For instance, Murniarti and Siahaan (2019) discovered that male students were confronted with more problems associated with career decision making while Tagay (2015) revealed that males' level of difficulty was lower than that for females in all grades. Bacanli (2016); Gali and Saka (2001) and Gineura, Nota, Soresi, and Gati's (2012) findings showed that females had greater difficulties in career decision making. Durosaro and Adebanke (2012) found that males and females showed different levels of career readiness. On the other hand, Albion (2001) differed completely as his findings revealed that adolescent boys and girls did not differ in the difficulties experienced in career decision making. This study, therefore, is important as it adds to the growing body of related literature on gender and career decision -making difficulties, which is expected to be relevant to secondary schools in Nigeria.

In Nigeria, the secondary school is a significant period of transition. It runs for six years of three years each in two phases namely Junior Secondary School (JSS) and Senior Secondary School (SSS). In SSS I the students are exposed to all the subjects and in SSS II, career decision is made. At this level, students are streamed into classes according to their career choice. Subjects selected are important because they will affect future careers. It is obvious that if students are not given adequate information, enlightenment, and counselled about the career decision-making process, it will create difficulties for students. This is why guidance and counselling services are highly needed.

\subsection{Purpose of the Study}

The main purpose of this study was to look at the difficulties being faced by secondary school students in Nigeria in career decision making. The study also sought to determine if differences existed between male and female students in the difficulties encountered.

\subsection{Research Questions}

Two research questions were asked to guide the study.
1. What are the difficulties encountered by secondary school students in career decision making in Nigeria?

2. What are the differences between male and female students in terms of the difficulties encountered in career decision making in Nigeria?

\subsection{Hypothesis}

One hypothesis was formulated for the study:

There is no significant difference between male and female secondary school students in terms of the difficulties encountered in career decision making in Nigeria.

\subsection{The Taxonomy of Difficulties}

The theoretical background for this study is based on the taxonomy of difficulties in career decision making by Gati et al (1996). This taxonomy is hinged on decision theory which is based on the construct of an "ideal career decision-maker". This simply refers to an individual who is conscious of the need to make a career decision and is capable of making the "right" decision. However, any deviation from the ideal career decision-maker is seen as a barrier that might, in turn, affect the process. The taxonomy according to Gati et al (1996) had three major categories of lack of readiness, lack of information, and inconsistent information. These were further categorized into ten (10) distinct problems or difficulties namely: lack of readiness, indecisiveness, dysfunctional myths, lack of knowledge about the process of a career decision, lack of information about the self, lack of information about occupations, lack of information about ways of obtaining additional information, inconsistent information: unreliable information, internal conflicts, and external conflicts.

\section{Methods}

\subsection{Population and Sampling}

The population of this study consists of all secondary school students in the Delta State of Nigeria, with a population size of 272,328 (Ministry of Basic and Secondary Education, 2019). Purposive sampling was used to select four schools and the subjects for this study were randomly selected. The participants were 341 students which included 161 males and 180 females.

\subsection{Instrument}

The instrument used in this study was the Career Decision-making Difficulties Scale (CDDQ) by Gati et al (1996) made up of 44 items. It was modified by the author to 39 items; five items were removed. The original 
response format was on a nine-point scale but this researcher modified it to a four-point response format of Strongly Agree, Agree, Strongly Disagree, and Disagree. The subjects were asked to rate on the four-point scale the degree to which each difficulty described them. The ten (10) distinct categories that make up the taxonomy of career decision-making difficulties were used in the study. The median Cronbach and reliabilities of the instrument were 0.78 and 0.77 .

The test-retest reliabilities reported by Gati et al (1996) were $0.67,0.74,0.72$, and 0.80 for the three main categories and the whole instrument. The author decided to do another reliability and validity to ascertain if the instrument can be used in Nigeria. The career decision-Making Difficulty Questionnaire (CDDQ) has some criticisms levelled against it by (Creed \& Yin, 2006; Tien, 2005; Vahedi, Farrokhi, Mahdavi, Moradi, 2012). Not paying attention to the affective areas which are capable of influencing both attitudes and information processing and these, in turn, can influence the process of career decision making. Despite these demerits, the strength of the CDDQ according to Vai Poulou et al (2019) is its solid theoretical base and ability to provide career decision-making difficulties assessment.

\subsubsection{Validity of the Instruments}

The instruments consisted of 44 items initially and when subjected to Principal Component Analysis and Varimax Rotation Method, with Kaiser Normalization, the items in the instrument, were reduced to 39 . For instance, lack of readiness scale now has 3 items; indecisiveness, scale, 2 items; dysfunctional myths scale, 3 items; lack of knowledge career decision scale, 3 items; lack of information scale, 7 items; lack of information about occupation scale, 4 items; lack of information about ways of obtaining information scale, 2 items; inconsistent information: unreliable information scale has 6 items; internal conflicts scale, 5 items; and external conflicts scale, 4 items.

Content validity of the scales revealed that lack of readiness scale accounted for $48.97 \%$ of the variance, indecisiveness scale, $61.23 \%$; dysfunctional myths scale, $55.02 \%$; lack of knowledge career decision scale, $58.95 \%$; lack of information scale, $65.46 \%$; lack of information about occupation scale, $63.55 \%$; lack of information about ways of obtaining information scale, $88.70 \%$. Inconsistent information: unreliable information scale, 54.86\%; internal conflicts scale, 46.6\%; external conflicts scale, $70.32 \%$ and difficulties in career decision-making scale, $77.98 \%$.

The construct validity of the scales was determined using the Factor Loadings Matrixes. For instance, the factor matrix for the instruments has the following ranges: lack of readiness scale range from .59 to .80 ; indecisiveness scale, from .75 to .78 ; dysfunctional myths scale, from .65 to .85 ; lack of knowledge career decision scale, from .61 to .86 ; lack of information scale, from .59 to .78; lack of information about occupation scale, from .77 to .91 ; lack of information about ways of obtaining information scale from .94 to 94 . Inconsistent information: unreliable information scale, from .59 to .78 ; internal conflicts scale, from .59 to .80 ; external conflicts scale, from .72 to .93 and difficulties in career decision making scale, from .48 to .70 .

\subsubsection{Reliability of the Instrument}

The researcher used the Cronbach Alpha method to determine the items' internal consistency in measuring what it is supposed to measure or the consistency in giving a similar score and the reliability of the instrument. The reliability coefficient of the instrument was 0.90 for the overall instrument. These figures indicate that the instrument was valid and reliable to be used in Nigeria.

\subsection{Data Analysis}

The data obtained were collated and entered into a computer system using the Statistical Package for Social Sciences (SPSS) version 24. Mean and the standard deviation was used to answer the research questions. The benchmarks used to answer the research questions are as follows: 6.00 for lack of readiness; 4.00 for indecisiveness, 6.00 for dysfunctional myth, 6.00 for lack of knowledge of the career decision process; 14.00 for lack of information about self; 8.00 for lack of information about the occupation; 4.00 for lack of information about ways of obtaining additional information about self; 12.00 for inconsistent information: Unreliable information; 10.00 for internal conflicts and 8.00 for external conflicts. The benchmark was obtained by calculating the average mean for all the items in each of the sub-categories. The independent samples t-test was used to test the null hypothesis at the 0.05 level of significance.

\section{Results}

Research Question 1: What are the difficulties encountered by secondary school students in career decision making? In answering research question 1, mean and standard deviation were computed. The result of data analysis is presented in Table 1 . 
Table 1. Means and standard deviations of difficulties encountered by secondary school students in career decision making

\begin{tabular}{|c|c|c|c|c|c|c|}
\hline Variables & $\mathbf{N}$ & Minimum & Maximum & Mean & Std. Deviation & Remark \\
\hline Lack of information & 341 & 1.00 & 32.00 & 17.92 & 6.30 & Difficult \\
\hline Inconsistent information: & 341 & 2.00 & 27.00 & 14.36 & 4.69 & Difficult \\
\hline Internal conflicts & 341 & 4.00 & 28.00 & 12.28 & 4.45 & Difficult \\
\hline $\begin{array}{c}\text { Lack of information about the } \\
\text { occupation }\end{array}$ & 341 & 2.00 & 25.00 & 9.84 & 3.53 & Difficult \\
\hline External conflicts & 341 & 1.00 & 17.00 & 9.53 & 3.59 & Difficult \\
\hline $\begin{array}{c}\text { Lack of knowledge of the career } \\
\text { decision process }\end{array}$ & 341 & 1.00 & 28.00 & 7.68 & 3.23 & Difficult \\
\hline Lack of readiness & 341 & 3.00 & 16.00 & 7.21 & 2.22 & Difficult \\
\hline Dysfunctional myth & 341 & 1.00 & 12.00 & 5.55 & 2.00 & Not Difficult \\
\hline $\begin{array}{c}\text { Lack of information about ways of } \\
\text { obtaining additional information } \\
\text { about self }\end{array}$ & 341 & 2.00 & 24.00 & 5.34 & 2.90 & Difficult \\
\hline Indecisiveness & 341 & 2.00 & 15.00 & 5.09 & 2.37 & Difficult \\
\hline
\end{tabular}

Table 2. Means and Standard Deviations Table showing Difficulties Encountered by Secondary School Students in Career Decision Making

\begin{tabular}{|c|c|c|c|c|c|c|}
\hline Variables & Sex & $\mathbf{N}$ & Mean & Std. Deviation & Mean Difference & Remark \\
\hline \multirow{2}{*}{ Lack of readiness } & Male & 161 & 7.22 & 2.15 & \multirow{2}{*}{.022} & High \\
\hline & Female & 180 & 7.19 & 2.29 & & High \\
\hline \multirow{2}{*}{ Indecisiveness } & Male & 161 & 5.32 & 3.02 & \multirow{2}{*}{.433} & High \\
\hline & Female & 180 & 4.88 & 2.30 & & High \\
\hline \multirow{2}{*}{ Dysfunctional myth } & Male & 161 & 5.47 & 1.93 & \multirow{2}{*}{.155} & Low \\
\hline & Female & 180 & 5.63 & 2.06 & & Low \\
\hline \multirow{2}{*}{$\begin{array}{l}\text { Lack of knowledge of the career decision } \\
\text { process }\end{array}$} & Male & 161 & 7.54 & 2.76 & \multirow{2}{*}{.265} & High \\
\hline & Female & 180 & 7.81 & 3.60 & & High \\
\hline \multirow{2}{*}{ Lack of information about self } & Male & 161 & 18.06 & 6.62 & \multirow{2}{*}{.279} & High \\
\hline & Female & 180 & 17.78 & 6.022 & & High \\
\hline \multirow{2}{*}{$\begin{array}{l}\text { Lack of information about the } \\
\text { occupation }\end{array}$} & Male & 161 & 9.95 & 3.58 & \multirow{2}{*}{.206} & High \\
\hline & Female & 180 & 9.74 & 3.49 & & High \\
\hline \multirow{2}{*}{$\begin{array}{c}\begin{array}{c}\text { Lack of information about ways of } \\
\text { obtaining additional information about } \\
\text { self }\end{array} \\
\end{array}$} & Male & 161 & 5.01 & 2.13 & \multirow{2}{*}{.626} & High \\
\hline & Female & 180 & 5.64 & 3.43 & & High \\
\hline \multirow{2}{*}{$\begin{array}{l}\text { Inconsistent information: Unreliable } \\
\text { information }\end{array}$} & Male & 161 & 14.61 & 4.77 & \multirow{2}{*}{.476} & High \\
\hline & Female & 180 & 14.14 & 4.62 & & High \\
\hline \multirow{2}{*}{ Internal conflicts } & Male & 161 & 13.07 & 4.85 & \multirow{2}{*}{1.491} & High \\
\hline & Female & 180 & 11.58 & 3.94 & & High \\
\hline \multirow{2}{*}{ External conflicts } & Male & 161 & 9.77 & 3.70 & \multirow{2}{*}{.459} & High \\
\hline & Female & 180 & 9.31 & 3.48 & & High \\
\hline
\end{tabular}

As shown in Table 1, lack of information has the highest number of difficulties encountered by secondary school students in career decision making with a mean of 17.92 and $\mathrm{SD}=6.30$; the second variable is Inconsistent information: unreliable information with a mean of 14.36 and $\mathrm{SD}=4.69$; the third is Internal conflicts with a mean of 12.28 and $\mathrm{SD}=4.45$; the fourth is Lack of information about occupation with a mean value of 9.84 and $\mathrm{SD}=3.53$; the fifth is External conflicts with a mean of 9.53 and $\mathrm{SD}=3.59$; the sixth is Lack of readiness with a mean of 7.21 and $\mathrm{SD}=2.22$; the eight is Dysfunctional myth with a mean of 5.55 and $\mathrm{SD}=2.00$, and the ninth is lack of information about ways of obtaining additional information about self with a mean value of 5.34 and $\mathrm{SD}=2.90$, and the tenth variable is indecisiveness with a mean value of 5.09 and
$\mathrm{SD}=2.67$. This provides an answer to research question 1 . The conclusion is that the secondary school students involved in this investigation have demonstrated evidence of career decision making difficulties in the nine discernable areas encountered in the study using the benchmark for each level. The dysfunctional myth was the only area they did not encounter difficulties.

Research Question 2: What are the differences between male and female secondary school students in terms of the difficulties encountered in career decision making?

To answer research question 2, the mean and standard deviation were used, as presented in Table 2.

As shown in Table 2, for lack of readiness, male students $(n=161)$ had a mean score of 7.22 while female students $(n=180)$ had a mean score of 7.19 , with a mean difference 
0.022; for Indecisiveness, male students $(\mathrm{n}=161)$ had a mean score of 5.32 while female students $(\mathrm{n}=180)$ had a mean score of 4.88 , with a mean difference 0.433 ; for Dysfunctional myth, male students $(\mathrm{n}=161)$ had a mean score of 5.47 while female students $(\mathrm{n}=180)$ had a mean score of 5.63 , with a mean difference 0.155 ; for Lack of knowledge of the career decision process, male students $(n=161)$ had a mean score of 7.54 while female students $(n=180)$ had a mean score of 7.81, with a mean difference 0.265 ; for Lack of information about self, male students $(\mathrm{n}=161)$ had a mean score of 6.62 while female students $(n=180)$ had a mean score of 6.02, with a mean difference 0.279 ; for Lack of information about the occupation, male students $(n=161)$ had a mean score of 3.58 while female students $(n=180)$ had a mean score of 3.49 , with a mean difference 0.206 ; for Lack of information about ways of obtaining additional information about self, male students $(\mathrm{n}=161)$ had a mean score of 5.01 while female students $(\mathrm{n}=180)$ had a mean score of 5.64, with a mean difference 0.626 ; for Inconsistent information: Unreliable information, male students $(n=161)$ had a mean score of 4.77 while female students $(n=180)$ had a mean score of 4.62 , with a mean difference 0.476; for Internal conflicts, male students $(n=161)$ had a mean score of 4.85 while female students $(\mathrm{n}=180)$ had a mean score of 3.94 , with a mean difference 1.491; and for External conflicts, male students $(\mathrm{n}=161)$ had a mean score of 9.77 while female students $(n=180)$ had a mean score of 9.31 , with a mean difference 0.459 . The result further showed that male and female students only had fewer difficulties in dysfunctional myth when compared with the benchmark calculated for the construct. This result implies that secondary school students in the study do not have difficulties in the area of dysfunctional myths.

Hypothesis 1: There is no significant difference between male and female secondary school students in terms of the difficulties encountered in career decision making.

To test hypothesis 1, t-test table was computed as presented in Table 3.

Table 3 shows the difficulties encountered by secondary school students in career decision making. The demographic data of sex was used. The result shows that gender was not a factor in career decision-making difficulties $(\mathrm{t}[339]=0.963 \mathrm{p}>0.05)$. Hence, the null hypothesis is accepted, which implies that there is no significant difference between male and female secondary school students in terms of the difficulties encountered in career decision making.

\section{Discussion of Findings}

The first finding revealed that secondary school students in the Delta State of Nigeria are experiencing career decision making difficulties in the nine distinct areas. The foremost difficulty experienced by students according to the analysis is the lack of information about themselves. This means that students lack information about their abilities, traits, and information about career-related preferences. This is followed by inconsistent information: Unreliable information and the fourth in the hierarchy of difficulty is lack of information about the occupation. If students have difficulties in all these areas, what type of career decision are we expecting? However, these findings are in agreement with Vaiopoulou et al (2019) whose findings among Greek students revealed a lack of information as constituting the highest difficulty facing students in career decision making. The result is that students will make inappropriate decisions. This is expected as most of the schools are without guidance counsellors vested with the responsibility for this role. The option is to depend on unreliable sources.

Table 3. T-test Table showing Difficulties Encountered by Secondary School Students in Career Decision Making

\begin{tabular}{|c|c|c|c|c|c|c|c|c|c|c|}
\hline \multicolumn{11}{|c|}{ Independent Samples Test } \\
\hline & & \multicolumn{2}{|c|}{\begin{tabular}{|c|} 
Levene's Test for \\
Equality of \\
Variances
\end{tabular}} & \multicolumn{7}{|c|}{ t-test for Equality of Means } \\
\hline & & \multirow[t]{2}{*}{$\mathrm{F}$} & \multirow[t]{2}{*}{ Sig. } & \multirow[t]{2}{*}{$\mathrm{t}$} & \multirow[t]{2}{*}{ df } & \multirow[t]{2}{*}{$\begin{array}{c}\text { Sig. } \\
\text { (2-tailed) }\end{array}$} & \multirow[t]{2}{*}{$\begin{array}{c}\text { Mean } \\
\text { Difference }\end{array}$} & \multirow[t]{2}{*}{$\begin{array}{l}\text { Std. Error } \\
\text { Difference }\end{array}$} & \multicolumn{2}{|c|}{$\begin{array}{l}95 \% \text { Confidence } \\
\text { Interval of the } \\
\text { Difference }\end{array}$} \\
\hline & & & & & & & & & Lower & Upper \\
\hline \multirow{2}{*}{$\begin{array}{c}\text { Career } \\
\text { Decision-Making } \\
\text { Difficulties }\end{array}$} & $\begin{array}{l}\text { Equal variances } \\
\text { assumed }\end{array}$ & 2.666 & .103 & .963 & 339 & .336 & 2.31929 & 2.40784 & -2.41689 & 7.05547 \\
\hline & $\begin{array}{c}\text { Equal variances not } \\
\text { assumed }\end{array}$ & & & .957 & 322.195 & .339 & 2.31929 & 2.42368 & -2.44896 & 7.08753 \\
\hline
\end{tabular}


Another difficulty identified is in the area of internal conflict and this is followed by an external conflict which has to do with the significant others. This area of external conflict is crucial especially in Nigeria where most parents want their children to take prestigious courses, like medicine, law, engineering among others even when the students have no abilities for such profession. This is corroborated further with Sarikaya and Khorshid's (2000) findings in Turkey. In this circumstance, there will be a clash within the students in career decision making. It is not limited to parents. There are also friends, family members, teachers who equally pose as threats to students in making their career decisions. Some parents want to mirror what they could not achieve in their children. This is further supported by Akpochafo (2017) who found that external influences, affect students in their career decision making. This poses a challenge when the individual's interests and abilities cannot cope with the preferred professions dictated by the significant others. This is supported by Akkoc, 2012a, b, Bancanli et al (2013) and as a result, the willingness to compromise is not there. Moreover, there is a problem with alternatives and preferences for other careers. The study further identified a lack of readiness and indecisiveness as difficult areas of career decision making among secondary school students. When counselling services are not put in place in the schools, how can the students be ready to make career decisions? Some of them just know that they have to decide on a career while in SSS II but they are not prepared for it. The study, however, observed that dysfunctional myth is not a difficult area of career decision making among secondary school students. It may be that the students believed that career would solve their problems in life. They always look forward to entering a career that will help them achieve their life goals.

The second finding revealed that male and female students only had fewer difficulties in dysfunctional myth when compared with the benchmark calculated for the construct. The finding also revealed mean differences between males and females in the nine areas with males experiencing more difficulties in seven categories and females in three categories. The males experience more difficulties in all areas of information except lack of information about ways of obtaining additional information about the self. This agrees with the study of Murniarti and Siahaan (2019), which revealed that male university students had more problems in making their career choices especially with regards to lack of information which showed in their work that more than half of the males did not receive enough information about the types of occupation they are to go in for. As for external conflict, boys experienced more difficulty which is in line with Gati and Saka (2001), whose study revealed that boys had greater difficulties than girls.

Since both males and females are experiencing difficulty in information but higher with males, the consequence is getting inconsistent and unreliable information since the schools have no way of providing authentic information. The students might rely on friends, other avenues and thus get fake news which according to Park and Rim (2019) can be influenced by social media.

As for indecisiveness, males experienced more difficulties, which disagrees with Bacanli (2015), whose study showed that female students had higher levels of difficulties than male students. But these differences are not significant as can be seen from the finding of the hypothesis.

The finding from the hypothesis revealed that gender was not a significant factor in the career-decision making difficulties encountered by secondary school students. This means that gender does not influence students' difficulties in making a career decision. This is not unexpected because most of the schools do not have counsellors; those that have counsellors do not have all that is required to practice full counselling (Akpochafo, 2018). These lead to career decision making difficulties that affect both male and female students. This finding agrees with the result of previous studies conducted in Switzerland where no gender difference was found in respect to career decision-making difficulties (Gati, et al., 2000; Vertzberger \& Gati, 2016). The finding also corroborated the study of Hsiu-Ian Shelly Tien (2001), which revealed that gender was not significant in the career decision-making scale. Albion (2001) is in partial agreement with this finding as, at times, girls report less difficulty, and at other times, the boys. On the other hand, the finding disagrees with the studies of Bacanli (2016), Tagay (2015), Guineura, Nota, Soresi, and Gati (2012), which revealed either males or females have more difficulties.

\section{Conclusions}

It can be concluded from the findings of this study using the CDDQ that secondary school students are faced with difficulties in making career decisions in nine areas except for dysfunctional myth. The analysis also revealed no gender differences in the difficulty level.

\section{Recommendations}

Based on the findings and conclusions of this study, the following recommendations are made:

1. Counsellors should realize from this study that nine out of the ten distinct levels posed as difficulties and so activities to enhance career decision making should be embarked on. To this end, seminars, workshops, conferences should be organized for secondary school students to alleviate these difficulties and build confidence in students to make good decisions. 
2. Counsellors in providing career interventions should give equal attention or opportunity to males and females as they both need assistance.

3. The government should post counsellors to secondary schools since they are to implement the recommendations and assist students in proper career decision making. The counsellors should be retrained in line with current global practices. This involves organizing seminars, workshops, and symposia for counsellors already on the job.

4. Moreover, the CDDQ used in this study can also be used in secondary schools for early identification of difficulties in Nigeria.

\section{Contribution}

The study has contributed to the growing body of knowledge of career decision making in Nigeria especially using the (CDDQ) questionnaire where there is no previous work on the taxonomy of difficulties before the author. The work has also clearly shown that no differences existed between males and females in career decision making. This will help to guide counselling effort.

\section{REFERENCES}

[1] Akkoc, F. (2012a). The relationship between the vocational indecision and career beliefs of high school students. Education Faculty Journal, 32, 49-70.

[2] Akkoc, F. (2012b). A study on high school students' vocational indecision according to demographic factors. University Journal of Education Faculty, 23, 215-233.

[3] Akpochafo, G.O. (2017). Locus of control as correlates of career decision making among secondary school students in the Delta The state of Nigeria. Journal of Education and Social Research, 7(2), 25-30.

[4] Akpochafo, G. O. (2018). Career development interventions implemented by counsellors in secondary schools in the Delta State of Nigeria. Journal of Emerging Trends in Educational Research and Policy Studies, 9(2), 40-44.

[5] Albion, M.J. (2000). Career decision-making difficulties of adolescent boys and girls. Australian Journal of Career Development, 9(2), 14-19, ISSN 1038-4162.

[6] Amir, T., \& Gati, I. (2006). Facets of career decision-making difficulties. British Journal of Guidance and Counselling, 34(4), 483-503.

[7] Bacanli, F. (2012a). Relationship between career decision-making difficulties and irrational beliefs about career choice. Turkish Psychological Counselling and Guidance Journal, 4(37), 86-95.

[8] Bacanli, F. (2016). Career decision making difficulties of Turkish adolescents. Internal Journal of Education and Vocational Guidance, $\quad 16, \quad 233-250$.
Doi10.1007/310775-015-9304-8.

[9] Bacanli, F., Esici, H., \& Ozunlu, B.M. (2013). An examination of career decision making difficulties according to several variables. Turkish Psychological Counselling and Guidance Journal, 5(40), 198-211.

[10] Bimrose, J., \& Mulvey, R. (2015). Exploring career decision-making styles across three European countries. British Journal of Guidance and Counselling, 43(3), 337-350. https://doi.org/10.1080/ 03069885. 2015.1017803.

[11] Creed, P., Prideaux, I.A., \& Patton, W. (2005). Antecedents and consequences of career decision state in adolescence. Journal of Vocational Behaviour, 67(30, 297-412. https// doi.org/ 10.1016/ JJVB.2004.08.008.

[12] Creed, P.A., \& Yin, W.O. (2006). Reliability and validity of a Chinese version of the career decision making difficulties questionnaire. International Journal for Educational and Vocational Guidance, 6, 47-63 DOI:10.1007/510775-006-0003-3.

[13] Di Fabio, A, Palazzeschi, L., Levin, N. and Gati, I. (2015). The role of personality in the career decision-making difficulties of Italian young adults. Journal of Career Assessment, 23(2), 281-293.

[14] Durosaro, I. and Adebanke, M. (2012). Gender as a factor in the career readiness of senior secondary school students in Ilorin metropolis of Kwara State, Nigeria. International Journal of Humanities and Social Science.

[15] Gati, H.B., \& Tal, S. (2008). Decision-making models and career guidance. International Handbook of Career Guidance 157-185. Dordrecht: Springer Netherlands. https//doiorg/10.1007/978-1-4020-6230-8B

[16] Gati, I, and Levin, N. (2014). Counselling for career decision-making difficulties. Measures and methods. Career Development Quarterly, 62, 98-113.

[17] Gati, I. and Levin, N. (2015). Making better career decisions. In P.J. Harting, M.L. Savickas, and W.B. Walsh (Eds.) APA handbook of career intervention, 2, 193-207. Washington, DC, US: American Psychological Association. https://doi.org/10.1037/14439.015.

[18] Gati, I. and Saka, N. (2001a). High school students' career-related decision-making difficulties. Journal of Counselling and Development, 79, 331-340. Doi:10.1002 /j.1556 -6676. 2001 tb01978.x

[19] Gati, I., Krausz, M. and Osipow, S.H. (1996). A taxonomy of difficulties in career decision making. Journal of Counselling Psychology, 43(3), 510-526.https//doi.org/10.1 037/0022-0167.43.4510.

[20] Gati, L. (1986). Making career decisions: A sequential elimination approach. Journal of Counselling Psychology, 33, 408-417 DOI:10.1037/0022.0167.33.4.408.

[21] Gati, I., Krausz, M., Osipow, S. H., \& Saka, N. (2000). The validity of the career decision-making difficulties questionnaire Counselee versus career counsellor perceptions. International Journal of Psychology, 35, 99-113. DOI:10.1006/jvbe.1999.1710

[22] Gineura, M.C., Nota, L., Soresi, S., and Gati, I. (2012). Career decision making profiles of Italian adolescents. Journal of Career Assessment, 20,

$375-389$. 
doi: $10.1177 / 1069072712448739$.

[23] Guan, Y., Chen, S.X., Levin, N., Bond, M.H., Luo, N., Xu, J. and Itan, X. (2015). Differences in career decision making profiles between America and Chinese university students. The relative strength of mediating mechanism across cultures. Journal of Cross-Cultural Psychology, https://doi.org/10.1177/0022022115585874.

[24] Hirschi, A. (2018). The fourth industrial revolution: Issues and implications for career research and practice. The Career Development Quarterly, 66(3), 192-204. https//doi.org/ 10. 1002 /cdq.12142.

[25] Mau, W.C.J. (2004). Cultural dimensions of career decision-making difficulties. Career Development Quarterly.https://doi.org/10.1002/j2161-0045.204.tb00656. $\mathrm{x}$.

[26] Murniarti, E., \& Siahaan, L.I. (2019). Millennials' career decision-making difficulties (CDMQ) in Indonesian university students. Advances in Social Sciences Research Journal, 6(9), 268-276. Doi:1014738/assrj.69.7079.

[27] Ozlem, Tagay (2015). Career decision-making difficulties in Turkey and the USA. International Journal of Recent Advances in Multidisciplinary Research, 02, 02, 0232-0239.

[28] Park, K., \& Rim, H. (2019). Social media hoaxes, political ideology, and the role of issue confidence. Telematics and
Informatics. https://doi.org/10.1016/j.tele.2018.11.001.

[29] Sabates, R., Gutmen, I., \& Schoon, I. (2017). Is there a wage penalty associated with a degree of indecision in career aspirations? Longitudinal and Life Course Studies, 8(3) https: //DOI.org/10.14301.

[30] Tien, H.L.S. (2001). Career decision-making difficulties perceived by college students in Taiwan. Bulletin of Educational Psychology, 33(10), 87-98.

[31] Tien, H.L.S. (2005). The validation of the career decision making difficulties scale in Chinese culture. Journal of Career Assessment, 13, 114-127. https: //doi.org /10.1177/ 1069072704270327.

[32] Vahedi, S., Farrokhi, F., Mahdavi, A., \& Moradi, S. (2012). Exploratory and confirmatory factor analysis of the career decision making difficulties questionnaire. Iranian Journal of Psychology, 7, 74-81.

[33] Vaiopoulou, J., Alexiou, I., \& Stamoviasis, D. (2019). Career decision-making difficulties and decision statuses among Greek student teachers. Hellenic Journal of Psychology, 16, 74-94.

[34] Vertsberger, D., \& Gati, I. (2016). Career decision-making difficulties and help-seeking among Israeli young adults. Journal of Career Development, 43, 145-159. DOI:10.1177/0894845315584162 